Jurnal

\title{
Diagnosis and Management of Marfan Syndrome
}

\author{
Andi Mahavira, Bambang B Siswanto
}

Division of Critical Care and Clinical Cardiology, Department of Cardiology and Vascular Medicine, Faculty of Medicine, University of Indonesia, and National Cardiovascular Center Harapan Kita, Jakarta, Indonesia
Background: Marfan syndrome is an autosomal dominant disorder of connective tissue, involving cardiovascular, ocular, skeletal and skin, pulmonary, and dura mater. Marfan syndrome is caused by mutations in the FBNI gene on chromosome I5q2I encoding fibrillin-I, a glycoprotein in the extracellular matrix. Prevalence is $\sim 2-3$ per 10000 , and $\sim 25-30 \%$ are new mutations. Morbidity and mortality mostly caused by dilation of the aortic root. Surgical therapy for aortic aneurysm can reduce life-threatening complication and also increase survival rate of Marfan syndrome. It is necessary to diagnose earlier and give appropriate medical therapy for optimal management of Marfan syndrome.

Objective: to present a rare case, Marfan syndrome, viewed from diagnosis and management.

Summary: A 32 year old woman diagnosed as severe AR was referred to NCCHK from Malang, East Java. According to several examination in clinic, this patient was diagnosed as severe AR on Marfan syndrome. Early diagnosis in Marfan syndrome will make better outcome. Bentall operation was done to this patient with a good result. Appropriate and continuous medical therapy are needed in post Bentall operation on Marfan syndrome patient.

(J Kardiol Indones. 2013;34:105-12)

Keywords: Marfan syndrome, diagnosis, surgical therapy, medical therapy 
Jurnal

Kardiologi Indonesia

J Kardiol Indones. 2013;34:105-12

ISSN $0126 / 3773$

\title{
Diagnosis dan Tatalaksana Sindrom Marfan
}

\author{
Andi Mahavira, Bambang B Siswanto
}

\begin{abstract}
Latar belakang: Sindrom Marfan adalah suatu kelainan jaringan ikat yang bersifat autosomal dominant, melibatkan sistem kardiovaskular, mata, rangka, kulit, paru-paru dan dura. Sindrom Marfan disebabkan oleh mutasi pada gen FBN1, yang terdapat pada Kromosom 15q21, yang mengkode fibrillin-1, suatu glikoprotein pada matrix extraselular. Prevalensi sindrom Marfan sekitar 2-3 per 10.000 penduduk dan sekitar 25-30\% adalah suatu mutasi baru. Penyebab morbiditas dan mortalitas tersering adalah dilatasi root dari aorta. Terapi bedah untuk aneurisma aorta dapat mengurangi komplikasi yang mengancam nyawa dan juga dapat meningkatkan angka harapan hidup seseorang dengan sindrom Marfan. Dibutuhkan diagnosis dini dan terapi medikamentosa yang tepat untuk tatalaksana yang optimal terhadap pasien sindrom Marfan.

Tujuan: Mempresentasikan kasus jarang yakni sindrom Marfan, ditinjau dari penegakan diagnosis dan tatalaksana.

Ringkasan: Seorang wanita 32 tahun dirujuk ke PJNHK dari Malang, Jawa Timur dengan diagnosis AR Severe. Melalui beberapa prosedur pemeriksaan selama di poliklinik, pasien ini di diagnosis AR severe pada sindrom Marfan. Penegakan diagnosis dini pada sindrom Marfan akan memberikan luaran klinis yang lebih baik. Pada pasien ini dilakukan operasi Bentall dengan hasil baik. Tatalaksana medikamentosa yang tepat dan berkelanjutan tetap diperlukan pada pasien sindrom Marfan pasca operasi Bentall.
\end{abstract}

(J Kardiol Indones. 2013;34:105-12)

Kata kunci: Sindrom Marfan, diagnosis, terapi bedah, terapi medikamentosa

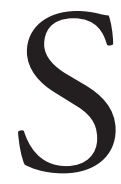
indrom Marfan adalah suatu kelainan jaringan ikat yang bersifat autosomal dominant, melibatkan sistem kardiovaskular, mata, rangka, kulit, paru-paru dan dura. Sindrom Marfan disebabkan oleh mutasi pada gen FBN1, yang terdapat pada Kromosom 15q21, yang mengkode fibrillin-1, suatu glikoprotein pada matrix extraselular. Prevalensi sindrom Marfan sekitar 2-3 per 10.000 penduduk dan

\section{Alamat Korespondensi:}

Dr. dr. Bambang Budi Siswanto, SpJP. Departemen Kardiologi dan Kedokteran Vaskular FKUI, dan Pusat Jantung Nasional Harapan Kita, Jln S Parman Kav 87 Jakarta I I 420. E-mail: bambbs@gmail.com sekitar $25-30 \%$ adalah suatu mutasi baru. ${ }^{1}$

Berdasarkan data catatan medis Pusat Jantung Nasional Harapan Kita (PJNHK), tercatat 39 kasus sindrom Marfan pada tahun 2006-2012, dan 6 kasus diantaranya dilakukan operasi katup aorta.

\section{Laporan Kasus}

Seorang wanita usia 32 tahun dirujuk ke Pusat Jantung Nasional Harapan Kita (PJNHK) dari dokter Spesialis Jantung dan Pembuluh Darah di Malang, Jawa Timur dengan diagnosis Severe Aortic Regurgitation untuk 
tatalaksana lebih lanjut. Pasien datang ke poliklinik PJNHK pada tanggal 6 Mei 2013. Keluhan utama pasien cepat lelah sejak 3 bulan sebelum masuk rumah sakit (SMRS), disertai sesak nafas yang muncul saat aktifitas. Pasien masih bisa tidur dengan 1 bantal. Keluhan terbangun pada malam hari karena sesak nafas tidak ada. Pasien dikatakan menderita sakit jantung sejak Februari 2013. Obat yang masih dikonsumsi pasien hingga saat itu adalah digoxin $1 \times 0.25 \mathrm{mg}$.

Pada pemeriksaan fisik didapatkan Tekanan darah $150 / 65$ mmHg, Nadi 88x per menit. Terdapat EDM grade 3/4 pada left sternal border. Corrigan pulse (+). Tinggi badan $166 \mathrm{~cm}$, berat badan $52 \mathrm{~cm}$, panjang kepala - puncak simfisis pubis $82 \mathrm{~cm}$, panjang simfisis - ujung kaki $87 \mathrm{~cm}$. Panjang tangan kanan-kiri yang dibentangkan $169 \mathrm{~cm}$. Pada pasien ini didapatkan wrist sign, thumb sign, planus pedis, skoliosis, dan lensa kacamata berukuran - 4 dioptri.

Pada pemeriksaan elektrokardiografi (EKG) (gambar 1) didapatkan irama sinus, laju QRS 90x/ menit, aksis QRS normal, gelombang P normal, interval PR 0.20 detik, durasi QRS 0.10 detik, perubahan segmen ST dan gelombang T tidak ada, LVH (+).

Pada pemeriksaan rontgen thorax (gambar 2) didapatkan CTR 52\%, segmen aorta elongasi, segmen pulmonal menonjol, pinggang jantung mendatar, apeks tertanam, kongesti tidak ada, infiltrat tidak ada, terdapat skoliosis. Pasien ini di diagnosis sebagai $\mathrm{CHF}$ ec $\mathrm{AR}$, dan direncanakan untuk pemeriksaan ekokardiografi dan CT Scan.

Pada pemeriksaan transthorakal ekokardiografi (gambar 3) tanggal 7 Mei 2013 didapatkan: EDD 65 $\mathrm{mm}$, ESD $40 \mathrm{~mm}$, TAPSE $2.5 \mathrm{~cm}$, EF $67 \%$, katup aorta 3 cuspis, dilatasi root aorta, uncoaptasi leaflet, AR severe, AR PHT 215 ms, diastolik reversal (+), end

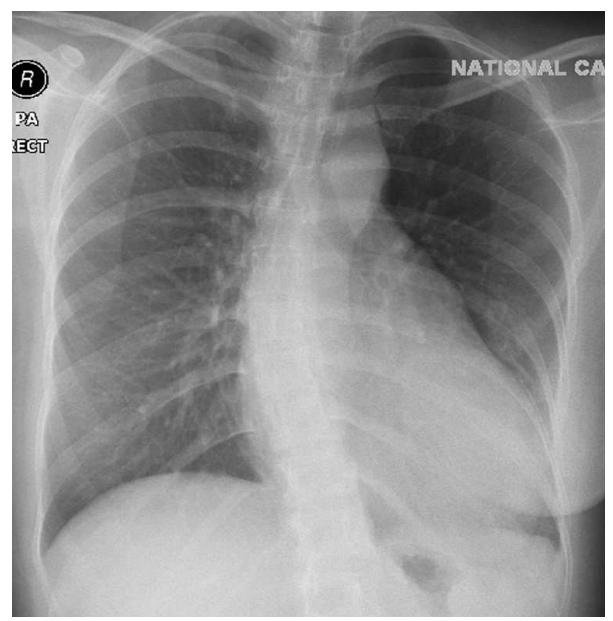

Gambar 2. Rontgen Thorax memperlihatkan CTR 52\%, segmen aorta elongasi, segmen pulmonal menonjol, dan skoliosis

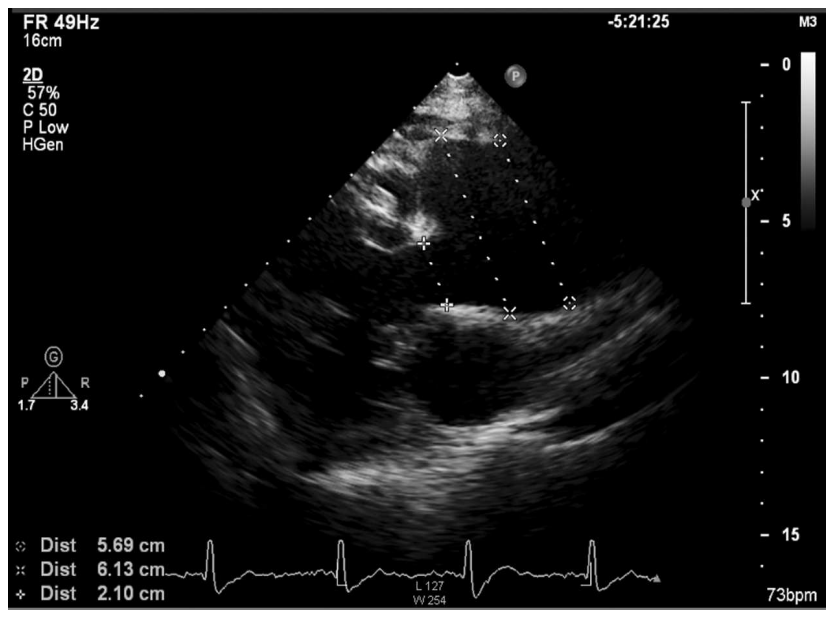

Gambar 3. Transthorakal Ekokardiografi memperlihatkan diameter root aorta $5.7 \mathrm{~cm}$, Sinus Valsava $6.1 \mathrm{~cm}$, dan $L V O T$ (anulus) $2.1 \mathrm{~cm}$

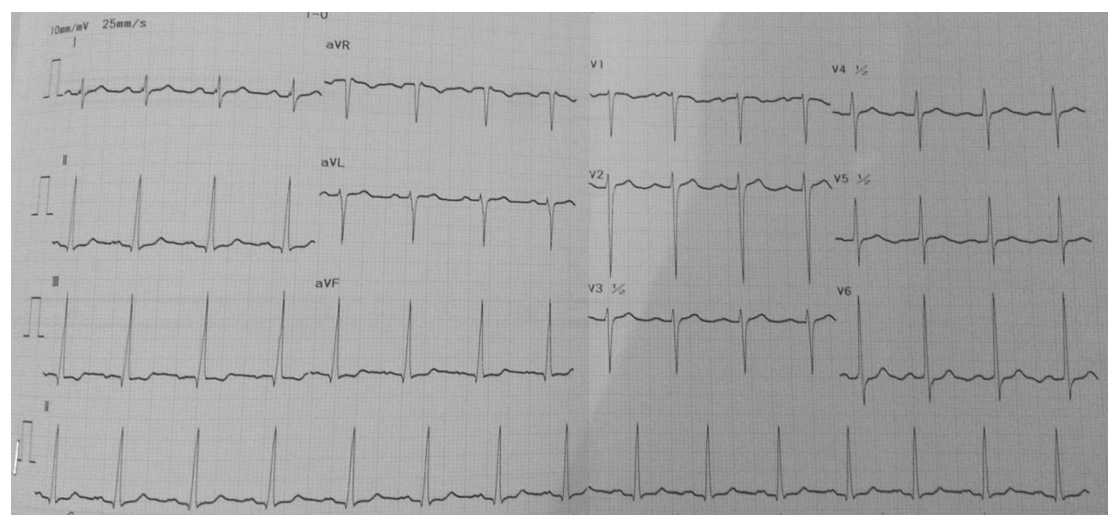

Gambar 1. Elektrokardiografi memperlihatkan irama sinus dan $L V H$ 


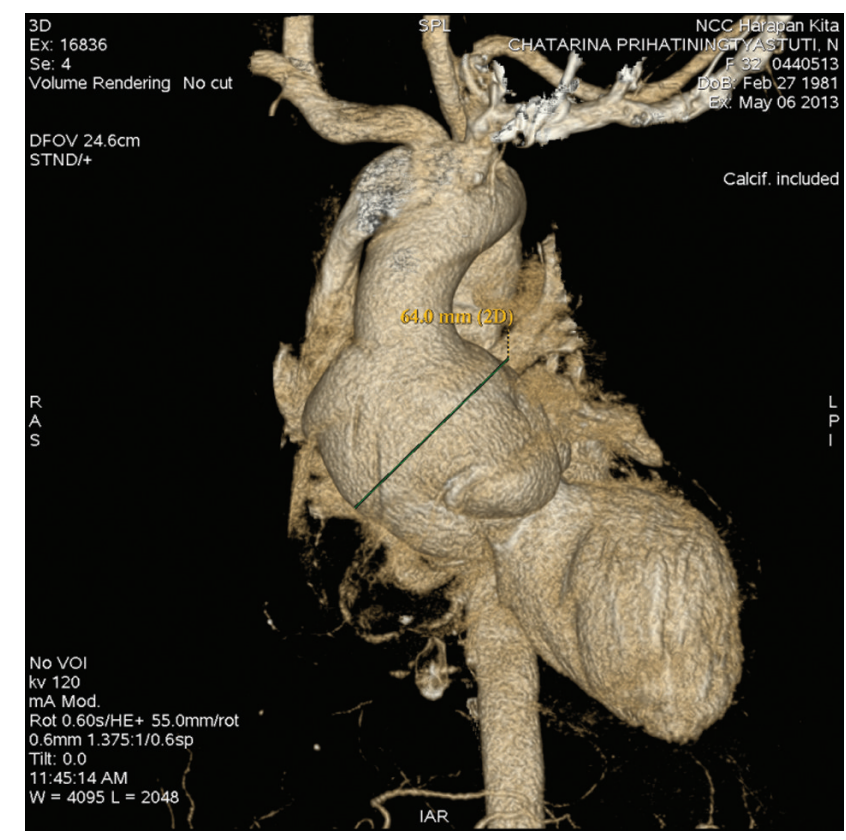

Gambar 4. CT Scan aorta memperlihatkan aneurisma aorta

diastolic velocity di aorta descenden $37 \mathrm{~cm} / \mathrm{s}$, diameter root aorta $5.7 \mathrm{~cm}$, sinus valsava $6.1 \mathrm{~cm}$, LVOT (anulus) $2.1 \mathrm{~cm}$, aorta descenden $6.0 \mathrm{~cm}$, arcus aorta $2.5 \mathrm{~cm}$. Kesimpulan: aneurisma aorta ascenden, $A R$ severe ec aneurisma aorta ascenden, Fungsi sistolik global $L V$ dalam batas normal, global normokinetik, Fungsi $R V$ dalam batas normal.

Pada pemeriksaan transesofageal ekokardiografi tanggal 7 Mei 2013 didapatkan aneurisma aorta ascenden sampai dengan arcus aorta, AR severe, uncoaptasi katup ec aneurisma, diameter sinus valsava $6.1 \mathrm{~cm}$ dan Root aorta $5.8 \mathrm{~cm}$, serta tidak terlihat diseksi.

Pada pemeriksaan CT scan tanggal 6 mei 2013 (gambar 4) didapatkan: dilatasi aneurisma root aorta $73.2 \mathrm{~mm}$, sepanjang $68-69 \mathrm{~mm}$, tidak terlihat diseksi sepanjang aorta, side branches dan arch vessels normal.

Pada tanggal 13 Juni 2013 pasien kontrol kembali ke poliklinik. Pasien diduga sebagai sindrom Marfan dan dikonsultasikan ke ahli genetik di Rumah Sakit Anak \& Bunda Harapan Kita. Hasil konsultasi dengan ahli genetik tersebut ditemukan bahwa pasien memiliki riwayat keluarga 3 generasi untuk sindrom Marfan. AR, aneurisma, miopia, dan arachnodactily juga didapatkan pada pasien ini.
Sesuai dengan kriteria Ghent, maka pasien didiagnosis sebagai sindrom Marfan. Kemudian pasien dijadwalkan untuk operasi pada tanggal 19 Juni 2013.

Pada tanggal 19 Juni 2013 pasien dilakukan operasi Bentall atas indikasi AR severe ec aneurisma aorta ascenden. Setelah selesai tindakan operasi, pasien dipindahkan ke ICU dewasa. Selama perawatan di ICU tidak ada masalah. Pada tanggal 20 Juni 2013 pasien dipindahkan ke IW bedah. Pasien dirawat di IW bedah selama 5 hari. Masalah selama di IW bedah: Hb 8.3 gr/dL. Pasien ditransfusi PRC. Pascatransfusi PRC, $\mathrm{Hb}$ menjadi $12.8 \mathrm{gr} / \mathrm{dL}$. Kemudian pasien dipindahkan ke gedung perawatan 2. Selama perawatan di gedung perawatan 2 tidak ada masalah. Pada tanggal 25 Juni 2013 keluhan pasien tidak ada. Tekanan darah pasien $118 / 59 \mathrm{mmHg}$, nadi $85 \mathrm{x} / \mathrm{menit}$, auskultasi jantung terdengar bunyi S1 dan S2 normal, tidak ada murmur, tidak ada gallop, terdengar metallic sound, auskultasi paru: vesikuler, tidak ada ronkhi dan wheezing.

Pada pemeriksaan ekokardiografi tanggal 25 Juni 2013 didapatkan: katup aorta prostetik mekanik, fungsi pergerakan baik, leakage (-). Fungsi sistolik $L V$ global baik dengan $E F 52 \%$. Kontraktilitas $R V$ menurun dengan TAPSE $1.1 \mathrm{~cm}$. PE mild.

Pada tanggal 29 Juni 2013 pasien dipulangkan dalam keadaan klinis baik dan hemodinamik stabil. Obat pasien saat pulang: bisoprolol $1 \times 5 \mathrm{mg}$, ramipril $1 \times 5 \mathrm{mg}$, warfarin $1 \times 1.5 \mathrm{mg}$, paracetamol $3 \times 1 \mathrm{gr}$ (prn).

Pada tanggal 11 Juli 2013 pasien kontrol ke poliklinik. Hasil lab INR 1.96. pasien diberikan obat bisoprolol $1 \times 5 \mathrm{mg}$, ramipril $1 \times 5 \mathrm{mg}$, warfarin $1 \times 3$ mg.

\section{Diskusi}

\section{Diagnosis}

Pada nosologi yang direvisi tahun 2010, kriteria diagnostik baru telah ditetapkan untuk pasien dengan atau tanpa riwayat keluarga yang didiagnosis sindrom Marfan (Tabel 1). Bila tidak terdapat riwayat keluarga dengan sindrom Marfan, diagnosis bisa ditegakkan dengan 4 skenario yang berbeda²:

1. Bila terdapat Dilatasi/diseksi root aorta dan ectopia lentis diagnosis sindrom Marfan dapat ditegakkan, terlepas dari ada atau tidaknya tanda-tanda sistemik kecuali terdapat hal yang menunjukkan 
Tabel 1. Kriteria Ghent yang direvisi untuk diagnosis sindrom Marfan dan kondisi yang berhubungan ${ }^{2}$

In the absence of family history:

(1) $A_{0}(Z \geq 2)$ AND EL $=M F S^{*}$

(2) Ao $(Z \geq 2)$ AND FBN1=MFS

(3) Ao ( $Z \geq 2)$ AND Syst $(\geq 7 \mathrm{pts})=$ MFS*

(4) EL AND FBN1 with known $A_{0}=$ MFS

EL with or without Syst AND with an FBN1 not known with Ao or no $F B N 1=$ ELS

Ao $(Z<2)$ AND Syst ( $\geq 5$ with at least one skeletal feature) without $\mathrm{EL}=\mathrm{MASS}$

MVP AND Ao $(Z<2)$ AND Syst $(<5)$ without $E L=M V P S$

In the presence of family history:

(5) EL AND FH of MFS (as defined above)=MFS

(6) Syst ( $\geq 7 \mathrm{pts}$ ) AND FH of MFS (as defined above) $=$ MFS*

(7) $A_{0}$ ( $Z \geq 2$ above 20 years old, $\geq 3$ below 20 years) $+F H$ of

MFS (as defined above) $=$ MFS*

Sphrintzen-Goldberg syndrome (SGS), LoeysDietz syndrome (LDS) atau bentuk vaskular dari Ehlers_Danlos syndrome (vEDS). ${ }^{2}$

2. Bila terdapat dilatasi/diseksi root aorta dan mutasi FBN1 cukup untuk menegakkan diagnosis jika tidak terdapat ectopia lentis. ${ }^{2}$

3. Bila terdapat dilatasi/diseksi root aorta tetapi tidak terdapat ectopia lentis dan status FBN1 masih belum diketahui atau negatif, diagnosis sindrom marfan dikonfirmasi oleh adanya temuan

Tabel 2. Nilai untuk kriteria sistemik ${ }^{2}$

- Wrist AND thumb sign - 3 (wrist OR thumb sign - 1)

- Pectus carinatum deformity -2 (pectus excavatum or chest asymmetry -1)

- Hindfoot deformity - 2 (plain pes planus -1)

- Pneumothorax -2

- Dural ectasia - 2

- Protrusio acetabuli - 2

- Reduced US/LS AND increased arm/height AND no severe scoliosis -1

- Scoliosis or thoracolumbar kyphosis - 1

- Reduced elbow extension - 1

- Facial features $(3 / 5)-1$ (dolichocephaly, enophthalmos, downslanting palpebral fissures, malar hypoplasia, retrognathia)

- Skin striae -1

- Myopia $>3$ diopters - 1

- Mitral valve prolapse (all types) - 1

Maximum total: 20 points; score $\geq 7$ indicates systemic

involvement; US/LS, upper segment/lower segment ratio. sistemik lainnya ( $\geq 7$ poin, sesuai dengan sistem skor yang baru) (tabel 2). Namun demikian, tanda-tanda yang mengesankan adanya SGS, LDS atau vEDS harus disingkirkan dan pemeriksaan genetik alternatif yang sesuai (TGFBR1/2, biokimia kolagen, COL3A1, pemeriksaan genetik lainnya yang relevan ketika diindikasikan) harus dilakukan. $^{2}$

4. Bila terdapat ectopia lentis tetapi tidak terdapat aortic root dilatation/diseksi, identifikasi mutasi FBN1 diperlukan sebelum mendiagnosis sindrom Marfan. Bila mutasi FBN 1 tidak berhubungan dengan penyakit kardiovaskular, pasien diklasifikasikan sebagai sindrom ectopia lentis. ${ }^{2}$

Pada pasien yang terdapat riwayat keluarga sindrom Marfan, diagnosis bisa ditegakkan bila terdapat ectopia lentis, atau skor sistemik $\geq 7$ atau aortic root dilatation dengan $Z \geq 2$ pada dewasa ( $\geq 20$ tahun) atau $Z \geq 3$ pada seseorang berusia kurang dari 20 tahun. $^{2}$

\section{Kriteria Sistemik}

Spesifisitas dan penggunaan untuk diagnostik dari manifestasi klinis pada sistem-sistem organ lainnya dievaluasi secara kritis oleh pendapat para ahli dan literatur yang ada. Beberapa manifestasi klinis dari kriteria minor pada nosology Ghent yang lama dihapuskan, tetapi kebanyakan dari tanda-tanda sistemik tetap terdapat pada kriteria sistemik (tabel $2)^{2}$.

Tiga poin ditetapkan untuk kombinasi thumb dan wrist signs. Thumb sign dikatakan positif bila seluruh tulang phalanx distal dari jempol yang diadduksi melebihi batas ulnar dari telapak tangan dengan bantuan atau tidak dibantu oleh pasien atau pemeriksa untuk mencapai adduksi yang maksimal. Wrist sign dikatakan positif bila ujung dari jempol menutup seluruh bagian dari kuku jari kelingking ketika kedua jari tersebut melingkari pergelangan tangan kontralateral. Bila hanya ada salah satu dari kedua pemeriksaan diatas, maka ditetapkan 1 poin ${ }^{2}$.

Dua poin ditetapkan untuk manifestasi sistemik spesifik lainnya yakni deformitas dada anterior, deformitas kaki bagian belakang, pneumothoraks spontan, dural ectasia , dan protrusi acetabulum. Pada sindrom Marfan, pectus carinatum diyakini lebih spesifik dibanding pectus excavatum dan ditetapkan 2 poin. Pectus excavatum atau dinding dada asimetris ditetapkan 1 poin. Hindfoot valgus (2 poin) dikombinasi 
dengan abduksi forefoot dan penurunan dari midfoot (yang dahulu dikatakan sebagai rotasi medial dari malleolus medialis) harus dievaluasi dari pandangan anterior-posterior. Pemeriksa harus membedakan hal ini dari 'flat foot' tanpa hindfoot valgus yang significant (1 poin). Setiap pneumothorax yang terjadi secara spontan tetap merupakan gambaran diagnostik. Untuk deteksi ektasia dura lumbosakral, tidak ada metode yang lebih disukai ( $C T$ atau $M R I)$ atau secara seragam dikatakan pada literatur dan kebijakan lokal. Ektasia dura bersifat sensitif tetapi bukan merupakan tanda yang spesifik untuk sindrom Marfan dan tidak lagi dikatakan setara dengan dislokasi lensa atau dilatasi aortic root. Ektasia dura sering terlihat pada LDS dan telah dideskripsikan pada mutasi yang terbukti vEDS. Protrusio acetabulum bisa dideteksi dengan menggunakan $x$-ray, $C T$ atau $M R I$. Pada $x$-ray pelvis AP, protrusio medial dari acetabulum yang sekurangkurangnya $3 \mathrm{~mm}$ melebihi garis ilio-ischial (Kohler) merupakan suatu hal diagnostik. Kriteria pada $C T$ atau $M R I$ belum ditetapkan, tetapi melibatkan hilangnya bentuk normal yakni bentuk oval pada inlet pelvis setinggi acetabulum. ${ }^{2}$

Satu poin ditetapkan pada delapan manifestasi klinis lainnya, satu pada sistem kardiovaskular (prolaps katup mitral), mata (miopi, $\geq 3$ dioptri), dan 6 gambaran dari sistem organ lainnya. Hal ini tidak spesifik pada sindrom Marfan dan bisa terlihat pada kelainan jaringan ikat lainnya atau variasi normal pada populasi. $^{2}$

Satu poin untuk kombinasi manifestasi klinis antara penurunan rasio segmen atas dan segmen bawah tubuh (untuk kaukasian <0.85; belum ada data pengukuran untuk orang Asia) dan peningkatan rasio tangan dibentangkan dengan tinggi badan (untuk dewasa $>1.05$ ) disertai dengan tidak adanya skoliosis yang bermakna. Pada orang Asia insidensi dari peningkatan rasio tangan dibentangkan dengan tinggi badan pada sindrom Marfan lebih rendah. Segmen bawah didefinisikan sebagai jarak dari puncak simfisis pubis ke lantai saat berdiri, dan segmen atas adalah tinggi dikurangi segmen bawah. Satu poin untuk skoliosis atau kifosis thorakolumbal. Ekstensi siku dikatakan menurun bila sudut antara lengan atas dan lengan bawah kurang dari $170^{\circ}$. Satu poin juga ditetapkan pada karakteristik wajah bila pasien memiliki 3 dari 5 karakteristik wajah yang tipikal yakni dolichocephaly, enophthalmos, fisura palpebra yang miring dan kebawah, retrognathia dan malar hipoplasia. Striae dikatakan suatu gambaran diagnostik yang bermakna jika letaknya pada daerah yang tidak umum seperti punggung bagian tengah, regio lumbal, lengan atas, axilaris dan paha, serta tidak berhubungan dengan perubahan berat badan yang mencolok atau hamil. $^{2}$

Kriteria-kriteria yang dihapuskan pada nosologi terbaru karena kurang spesifik yakni hipermobilitas sendi, highly arched palate, dan hernia insisional atau rekuren. ${ }^{2}$

Berdasarkan dengan kriteria nosologi Ghent yang direvisi tahun 2010, pasien ini didiagnosis sindrom Marfan. Pada pasien ini terdapat riwayat keluarga sindrom Marfan dan dilatasi aorta. Skor sistemik dari pasien ini 6 poin yang terdiri dari wrist sign dan thumb sign positif (3 poin), planus pedis (1 poin), skoliosis (1 poin), dan miopia (1 poin).

\section{Tatalaksana}

Terapi medis dan bedah telah meningkatkan angka harapan hidup hingga 60-70 tahun. ${ }^{1}$

\section{a. Penghambat $\beta$}

Penghambat $\beta$ dapat mengurangi kecepatan dilatasi aorta dan meningkatkan kelangsungan hidup, setidaknya pada orang dewasa. ${ }^{1}$ Penggunaan penghambat adrenergik untuk mengurangi stres hemodinamik di aorta proksimal pada sindrom Marfan pertama kali pada tahun 1971. ${ }^{2}$ Pengobatan menggunakan penghambat $\beta$ dengan mengurangi denyut ejeksi sistolik dapat mengurangi risiko diseksi aorta. ${ }^{3}$ Dalam suatu studi menunjukkan bahwa penghambat $\beta$ dengan propranolol, atenolol atau metoprolol meningkatkan distensibilitas aorta dan mengurangi kekakuan aorta pada pasien sindrom Marfan. ${ }^{4}$ Studi-studi tersebut memberikan bukti kuat bahwa penghambat $\beta$ harus dipertimbangkan pada semua pasien sindrom Marfan, terutama pada kelompok usia muda. ${ }^{4}$ Pada pasien ini diberikan bisoprolol 1x5mg sejak tanggal 20 Juni 2013.

\section{b. Angiotensin II receptor blocker}

Angiotensin II reseptor blocker (ARB) seperti losartan berpotensi sebagai antagonis TGF- $\beta .{ }^{1}$ Pada suatu studi pada tikus, aktivasi TGF- $\beta$ yang abnormal memperlihatkan manifestasi sindrom Marfan terhadap sistem kardiovaskular, paru, rangka dan otot rangka. ${ }^{3}$ Suatu studi prospektif menunjukkan kombinasi obat losartan dan penghambat $\beta$ pada pasien sindrom Marfan yang diberikan selama 35 bulan tersebut 
terbukti lebih efektif dibandingkan dengan pemberian penghambat $\beta$ saja dalam memperlambat atau bahkan menurunkan dilatasi root aorta pada pasien sindrom Marfan. ${ }^{5}$ Selama perawatan di PJNHK pasien tidak mendapatkan Losartan. Namun, saat ini pasien sudah mengkonsumsi Losartan 1x25 mg.

\section{c. Doxycycline}

Doxycycline telah terbukti efektif menjadi penghambat MMPs dan baru-baru ini telah terbukti memiliki peran yang menguntungkan dalam pengurangan kadar MMP aorta pada model sindrom Marfan di hewan. Matriks metalloproteinase (MMP)-2 dan -9 yang diregulasi selama perkembangan TAA (thoracic aortic aneurysm) pada sindrom Marfan, disertai dengan menurunnya elastis serat dan disfungsi vasomotor. Hipotesis menunjukkan bahwa mekanisme menguntungkan dari doxycycline terutama dimediasi oleh efek inhibisi terhadap MMP-2 dan -9. Dalam penelitian ini disimpulkan bahwa doxycycline, lebih baik dalam menjaga integritas serat elastin, sifat mekanik aorta, fungsi kontraktilitas sel otot polos aorta, dan relaksasi endotelium dibanding atenolol, dengan demikian menekan perkembangan TAA. ${ }^{8}$ Pada pasien ini tidak diberikan terapi doxycycline karena belum ada penelitian obat doxycycline pada manusia.

\section{d. Operasi Aorta}

Dilatasi aorta dapat menyebabkan diseksi aorta dan atau disfungsi dari katup aorta. ${ }^{4}$ Berdasarkan sejumlah penelitian, menunjukkan hasil yang lebih baik terhadap root aorta pada operasi yang dilakukan lebih awal dibandingkan dengan pembedahan kemudian atau pembedahan darurat. ${ }^{4}$ Profilaksis operasi dianjurkan ketika diameter pada sinus valsava melebihi $5,5 \mathrm{~cm}$ pada orang dewasa dan $5,0 \mathrm{~cm}$ pada anak-anak. ${ }^{4}$ Data kelangsungan hidup juga menunjukkan peningkatan umur yang panjang pasien sindrom Marfan yang menjalani bedah profilaksis, dibandingkan dengan mereka yang tidak dilakukan bedah profilaksis. ${ }^{4}$ Sampai saat ini, sebagian besar ahli bedah jantung lebih memilih prosedur bedah Bentall composite graft repair, dimana root aorta dan katup aorta diganti. ${ }^{4}$ Penggantian komposit dari katup aorta dan aorta asendens memiliki risiko rendah dan operasi yang sangat tahan lama pada pusat kesehatan yang berpengalaman (mortalitas operasi dilaporkan 1,5\% untuk elektif dan $11,7 \%$ untuk operasi darurat). ${ }^{1}$ Telah dilaporkan angka kelangsungan hidup 5 dan 10 tahun yaitu $84 \%$ dan $75 \% .{ }^{1}$ Walaupun demikian Sindrom
Tabel 3. Indikasi Operasi Aorta pada sindrom Marfan ${ }^{1}$

\begin{tabular}{|c|c|c|}
\hline Indications & Class" & Level ${ }^{\mathrm{b}}$ \\
\hline \multicolumn{3}{|l|}{$\begin{array}{l}\text { Patlents should undergo surgery when aortic } \\
\text { root maximal diameter is: }\end{array}$} \\
\hline$\cdot>50 \mathrm{~mm}$ & I & Ce \\
\hline $\begin{array}{l}\text { * 46-50 mm with } \\
\text { - famlly history of dissection or }\end{array}$ & I & C \\
\hline $\begin{array}{l}\text { - progressive dilation }>2 \text { mmlyear as } \\
\text { confirmed by repeated measurement or }\end{array}$ & I & C \\
\hline - severe AR or MR or & I & C \\
\hline - desire of pregnancy & I & C \\
\hline $\begin{array}{l}\text { Patlents should be considered for surgery } \\
\text { when other parts of the aorta }>50 \mathrm{~mm} \text { or } \\
\text { dilation is progressive }\end{array}$ & Illa & C \\
\hline
\end{tabular}

Marfan mempunyai risiko jauh lebih tinggi terhadap kejadian diseksi aneurisma aorta dibandingkan dari etiologi penyakit aorta lainnya. ${ }^{1}$ Indikasi operasi aorta pada sindrom Marfan seperti yang tertera pada Tabel 3, direkomendasikan operasi bila diameter maksimal dari root aorta: (1) $>50 \mathrm{~mm}$, (2) 46-50 $\mathrm{mm}$ dengan riwayat keluarga dengan diseksi aorta atau dilatasi progresif $>2 \mathrm{~mm} /$ tahun yang dikonfirmasi dengan pengukuran berkala atau AR/MR severe atau berkeinginan untuk hamil. ${ }^{1}$

Pada pasien sindrom Marfan, operasi dilakukan bila diameter aorta ascenden $\geq 50 \mathrm{~mm}$ seperti yang tertera pada tabel $4 .{ }^{6}$ Bila terdapat faktor risiko seperti riwayat keluarga dengan diseksi aorta, peningkatan ukuran diameter aorta $>2 \mathrm{~mm} /$ tahun; AR severe; berkeinginan untuk hamil, tindakan operasi harus dipertimbangkan pada diameter root aorta $\geq 45 \mathrm{~mm}^{6}{ }^{6}$

Pasien sindrom Marfan ini diindikasikan untuk dilakukan operasi karena terdapat $A R$ dan diameter root aorta $57 \mathrm{~mm}$. Operasi Bentall dilakukan pada pasien sindrom Marfan ini dengan hasil baik yang dievaluasi melalui ekokardiografi.

\section{Ringkasan}

Seorang wanita 32 tahun dirujuk ke PJNHK dari Malang, Jawa Timur dengan diagnosis AR Severe. Melalui beberapa prosedur pemeriksaan selama di poliklinik, pasien ini di diagnosis $A R$ severe pada sindrom Marfan. Penegakan diagnosis dini pada sindrom Marfan akan memberikan luaran klinis yang 
Tabel 4. indikasi operasi pada regurgitasi aorta ${ }^{6}$

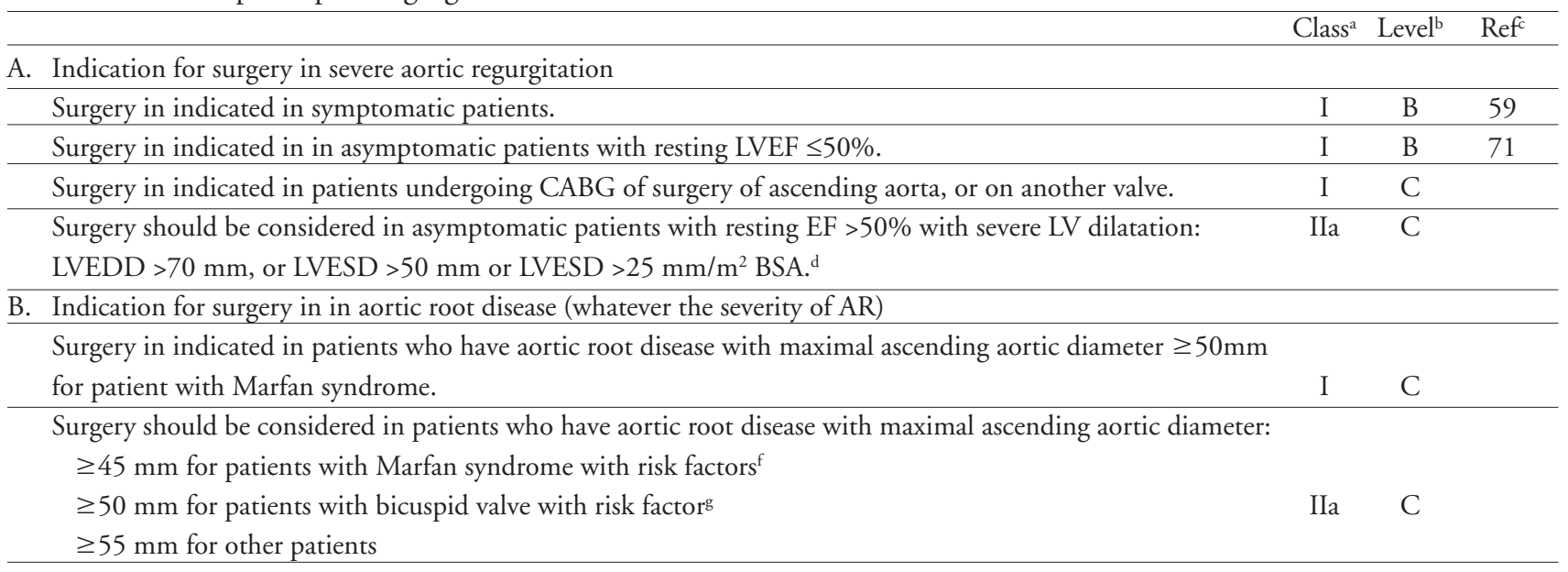

lebih baik. Pada pasien ini dilakukan operasi Bentall dengan hasil baik. Tatalaksana medikamentosa yang tepat dan berkelanjutan tetap diperlukan pada pasien sindrom Marfan pasca operasi Bentall.

\section{Daftar Pustaka}

1. Baumgartner H, Bonhoeffer P, De Groot NM, et al. ESC Guidelines for the management of grown-up congenital heart disease (new version 2010). European heart journal 2010;31:291557

2. Loeys BL DH, Braverman AC, Callewaert BL, et al. The revised Ghent nosology for the Marfan syndrome. J Med Genet 2010. 2010;47:476-85.

3. Keane MG, Pyeritz RE. Medical management of Marfan syndrome. Circulation 2008;117:2802-13

4. Dean JC. Management of Marfan syndrome. Heart 2002;88:97103
5. Chiu HH, Wu MH, Wang JK, et al. Losartan Added to b-Blockade Therapy for Aortic Root Dilation in Marfan Syndrome:A Randomized, Open-Label Pilot Study. Mayo clinic proceedings 2013;88(3):271-276

6. Vahanian A, Alfieri O, Andreotti F, et al. Guidelines on the management of valvular heart disease: The Joint Task Force on the Management of Valvular Heart Disease of the European Society of Cardiology (ESC) and the European Association for Cardio-Thoracic Surgery (EACTS). European heart journal 2012;33:2451-96

7. Cozijnsen L, Braam RL, Waalewijn RA, et al. What is new in dilatation of the ascending aorta? Review of current literature and practical advice for the cardiologist. Circulation 2011;123:924-8

8. Chung AW, Yang HH, Radomski MW, van Breemen C. Longterm doxycycline is more effective than atenolol to prevent thoracic aortic aneurysm in marfan syndrome through the inhibition of matrix metalloproteinase-2 and -9. Circulation research 2008;102:e73-85 